\title{
Frequency of Vitamin-D deficiency in children with Urinary tract infection: A descriptive cross-sectional study
}

\author{
Saba Qadir ${ }^{1}$, Shazia Memon ${ }^{2}$, \\ Muhammad Nadeem Chohan ${ }^{3}$, Yasmeen Memon ${ }^{4}$
}

\begin{abstract}
Objective: To determine Vitamin-D status in children with urinary tract infection.

Methods: A Cross-sectional study was done at Pediatric Department, Liaquat University Hospital Hyderabad, from July 2019 to March 2020. A total of 172 children of either gender from 2 to 60 months of age with confirmed urinary tract infection (UTI) (having positive urine C/S report) were included in the study. The child who received antibiotics 48 hours prior or already on immunosuppressive drugs and steroids from previous health record or by taking clinically relevant history), children with CKD on vitamin-D supplementation, and known case of Vitamin-D deficiency were also excluded from the study. All study participants were evaluated for vitamin-D level by high performance liquid chromatography. Urine sample was collected for C/S and $1 \mathrm{cc}$ venous blood was taken for Vitamin D status ( $\mathrm{ng} / \mathrm{ml}$ ). The mean \pm standard deviation (SD) and stratification was calculated for age, duration of urinary tract infection and vitamin-D level. Post stratification chi-square test was applied for all categorical variables at $95 \%$ confidence interval $(\mathrm{Cl})$ and $\mathrm{P}$-value $\leq 0.05$ was considered significant.
\end{abstract}

Results: The average age of the patients was $41.51 \pm 18.34$ months. There were $130(75.58 \%)$ females and $40(23.25 \%)$ males. Most common complaint of the children was fever 150 (87.21\%). Vomiting was present in $31(18.02 \%)$, abdominal pain $22(12.79 \%)$ and dysuria in $15(8.72 \%)$ children. A total of $129(75 \%)$ children had pyelonephritis and $15(25 \%)$ had cystitis. (Frequency of vitamin-D deficiency in children with diagnosed UTI was $45.93 \%(79 / 172)$. Mild vitamin D deficiency was present in $42(53.16 \%)$ children, while moderate deficiency in $55(69.62 \%)$ children. E. Coli was the most common pathogen in both mild and moderate vitamin $\mathrm{D}$ deficiency i.e., 20 (47.61) and 31 (56.36\%) respectively.

Conclusion: The frequency of urinary tract infection is more common in children having vitamin $D$ deficiency.

KEYWORDS: Children, Urinary Tract Infection, Vitamin D deficiency.

doi: https://doi.org/10.12669/pjms.37.4.3896

How to cite this:

Qadir S, Memon S, Chohan MN, Memon Y. Frequency of Vitamin-D deficiency in children with Urinary tract infection: A descriptive cross-sectional study. Pak J Med Sci. 2021;37(4):1058-1062. doi: https://doi.org/10.12669/pjms.37.4.3896

This is an Open Access article distributed under the terms of the Creative Commons Attribution License (http://creativecommons.org/licenses/by/3.0), which permits unrestricted use, distribution, and reproduction in any medium, provided the original work is properly cited.

Correspondence:

Dr. M. Nadeem Chohan, Assistant Professor,

Pediatrics Department,

LUMHS, Jamshoro, Pakistan.

Postal Address: House \# A-251 Phase-1,

Sindh University Housing Employee Cooperative Society,

Jamshoro, Sindh, Pakistan.

Email: nadeem.chohan@lumhs.edu.pk

* Received for Publication:

* Revision Received:

* Revision Accepted:
November 9, 2020

February 23, 2021

March 5, 2021

\section{INTRODUCTION}

Vitamin-D has a vital role in the immune regulation, and it has a systemic effect on pathogens. ${ }^{1,2}$ Vitamin D deficiency can cause hypocalcemia that reduces the function of neutrophils and lymphocytes. ${ }^{3}$ There are various functions of Vitamin-D including suppression of cytokines, like suppuration of cytokine (IL6, IL 8) and inflammatory cascade taking place after attachment of pathogen to uroepithilium, 
thereby it may limit the severity of UTI ${ }^{4}$ hence suppress the effect of infection. Deficiency of vitamin-D is associated with sepsis, pneumonia, and influenza. ${ }^{5}$ In previous studies Vitamin-D deficiency was associated with UTI; ${ }^{6}$ having the prevalence of $20 \% .^{7}$

UTI is a common diagnosis in children. It can cause abdominal pain, fever, frequency, dysuria and hematuria. In the first year of life UTI is most common in boys than girls but afterwards it is more common in girls. There are various risk factors for UTI like congenital anomalies of kidneys and urinary tract (PUV and VUR), constipation and bladder dysfunction. Prevalence of UTI in girls is $3-5 \%$ and $1 \%$ in boys. ${ }^{8}$ About $5 \%$ of febrile girls in infancy presents with UTI, while $20 \%$ of uncircumscribed boys present with UTI. Escherichia coli infection is the most common pathogen $(80 \%$ to $90 \%)$ causing the UTI. ${ }^{9}$

Vitamin-D Supplementation before and during the episode of urinary tract infection can improve the clinical status. ${ }^{10}$ Vitamin-D Supplements are available in market at reasonable price. UTI can be managed more appropriately by using both vitamin-D supplements and antibiotics. This practice may decrease the misuse of antibiotics hence reducing the cost of management. Epithelium derived cathelicidin is the first line defense mechanism against the bacteria's causing UTI. Cathelicidin is produced by epithelium of urinary tract during infection. ${ }^{11}$ Cathelicidin has a defined vitamin-D dependent mechanism. Bacterial adherence to urinary tract mucosa leads to the production of cathelicidin. ${ }^{12}$ Normal Vitamin-D levels in serum is mandatory for the optimal cathelicidin production by macrophages. ${ }^{13}$

There is no local study that has assessed the impact of vitamin-D level on UTI, thus this study is relevant and specific to generate local data by evaluating the magnitude of vitamin-D deficiency in children with UTI and to compare our results with international literature. Our objective was to find out the frequency of vitamin-D deficiency in children with diagnosed UTI.

\section{METHODS}

This cross-sectional study was conducted at Pediatric Department, Liaquat University Hospital, Jamshoro/Hyderabad by from 02-072019 to 14-03-2020. Non probability consecutive sampling technique was used and sample size was calculated by taking Vitamin-D deficiency prevalence in urinary tract infection as $20 \% ;^{7}$ with $6 \%$ margin of error. Total 172 children with urinary tract infection were taken in this study.

All children of two to sixty months of age, of either gender with suspicion of urinary tract infection based on clinical features (like dysuria, hematuria, abdominal pain, pack pain, increased frequency of urine, history of fever), were worked up by urinalysis and urine culture and sensitivity. Urine CS positive $\left(>10^{5}\right.$ colonies of a single urinary tract pathogen / $\mathrm{ml}$ of urine specimen) were included in the study. Children with malnutrition and other systemic illness were excluded. The child who received antibiotics 48 hours prior or already were on immunosuppressive drugs and steroids from previous health record or by taking clinically relevant history), children with CKD on Vitamin-D supplementation, and known case of vitamin-D deficiency were also excluded from the study.

Table-I: General characteristics of study participants $(n=172)$.

\begin{tabular}{|c|c|c|}
\hline \multirow[t]{2}{*}{ Characteristic } & $N$ & $\%$ \\
\hline & Mean & $\begin{array}{l}\text { Standard } \\
\text { Deviation }\end{array}$ \\
\hline Age & 41.51 & 18.34 \\
\hline$<12$ (months) & 34 & 19.77 \\
\hline 13-48 (months) & 73 & 42.44 \\
\hline >48 (months) & 65 & 37.79 \\
\hline \multicolumn{3}{|l|}{ Gender } \\
\hline Male & 132 & 76.74 \\
\hline Female & 40 & 23.26 \\
\hline \multicolumn{3}{|l|}{ Clinical Features } \\
\hline Fever & 150 & 87.21 \\
\hline Vomiting & 31 & 18.02 \\
\hline Abdominal pain & 22 & 12.79 \\
\hline Dysuria & 15 & 8.72 \\
\hline \multicolumn{3}{|l|}{ Vitamin D Status } \\
\hline Mean & 20.33 & $\mathrm{SD} \pm 15.0$ \\
\hline Mild Deficiency & 42 & $53.16 \%$ \\
\hline Moderate Deficiency & 55 & $69.62 \%$ \\
\hline
\end{tabular}


Children presenting to pediatric out door department with suspicion of urinary tract infection were recruited in study by taking consent from attendant / guardian of the children and by collecting urine sample of around $10 \mathrm{ml}$ under aseptic measures in sterile urinary bottle and send to laboratory for analysis. Urine specimen was taken by urinary catheterization in all children If urine sample was not analyzed within 10 minutes, then it was refrigenetad and analyzed later on. All children with suspected urinary tract infection whose urine $C / S$ report became positive were evaluated and explored in laboratory for Vitamin-D deficiency $(\leq 20 \mathrm{ng} / \mathrm{ml}$ ) (by taking one cc venous blood in a sterilize syringe. Vitamin-D was measured by high performance liquid chromatography. All the specimens were examined by senior pathologist of diagnostic and research laboratory, having more than three years' clinical laboratory experience. Data collection like Urine C/S and Serum vitamin D level and all such maneuvers (relevant history, specific clinical examination and sampling) was performed by principal researcher. All expenses were born by the researcher. This study was done after the approval of CPSP (CPSP/REU/PED-164-3854).
Serum vitamin-D level $\leq 20 \mathrm{ng} / \mathrm{ml}$ was labelled as vitamin-D deficiency. ${ }^{14}$ Urinary tract infection was labelled when urine culture showed growth of $>10^{5}$ colonies of a single urinary tract pathogen / $\mathrm{ml}$ of urine specimen.

SPSS version 22.00 was used for data analysis. The frequency and percentage (\%) were calculated for age, gender, fever, and vitamin-D deficiency. The mean \pm standard deviation (SD) and stratification was calculated for age, duration of urinary tract infection and vitamin-D level.

Post stratification chi-square test was applied for all categorical variables at $95 \%$ confidence interval (CI) and P-value $\leq 0.05$ was considered significant.

\section{RESULTS}

Total 172 children with confirmed UTI were included in this study. Baseline characteristics are shown in Table-1. The average age of the patients was $41.51 \pm 18.34$ months and mean vitamin-D level was $-20.33 \mathrm{SD} \pm 15.0$. There were $132(76.74 \%)$ male and $40(23.6 \%)$ females. Most of the children had fever 150 (87.21\%) (Table-I). Frequency of vitamin-D deficiency in children with diagnosed UTI was $45.93 \%$ (79/172). It was not statistically significant among age groups

Table-II: Vitamin-D status in children with UTI $(\mathrm{n}=172)$.

\begin{tabular}{|c|c|c|c|c|}
\hline \multirow[b]{2}{*}{$\begin{array}{l}\text { Age Groups } \\
\text { (months) }\end{array}$} & \multicolumn{2}{|c|}{ Vitamin-D status } & \multirow[t]{2}{*}{ Total } & \multirow[t]{2}{*}{ P-Value } \\
\hline & $\begin{array}{c}V D \text { deficient } \\
\text { Yes } \\
N=79(45.93 \%)\end{array}$ & $\begin{array}{c}\text { Normal VD } \\
\text { No } \\
N=93\end{array}$ & & \\
\hline$\leq 12$ & $18(52.9 \%)$ & $16(47.1 \%)$ & 34 & \\
\hline $13-48$ & $33(45.2 \%)$ & $40(54.8 \%)$ & 73 & 0.637 \\
\hline$>48$ & $28(43.1 \%)$ & $37(56.9 \%)$ & 65 & \\
\hline \multicolumn{5}{|l|}{ Gender } \\
\hline Male & $55(41.7 \%)$ & $77(58.3 \%)$ & 132 & 0.042 \\
\hline Female & $24(60 \%)$ & $16(40 \%)$ & 40 & \\
\hline \multicolumn{5}{|l|}{ Fever } \\
\hline Yes & $69(46 \%)$ & $81(54 \%)$ & 150 & 0.962 \\
\hline No & $10(45.5 \%)$ & $12(54.5 \%)$ & 22 & \\
\hline \multicolumn{5}{|c|}{ Duration of UTI } \\
\hline$\leq 5$ days & $52(47.7 \%)$ & $57(52.3 \%)$ & 109 & 0.539 \\
\hline$>5$ days & $27(42.9 \%)$ & $36(57.1 \%)$ & 63 & 0.531 \\
\hline
\end{tabular}


Table-III: Pathogens according to Vitamin D Status.

\begin{tabular}{lcc}
\hline Pathogens & Number & $\%$ \\
\hline Mild Deficiency & 42 & \\
Escherichia. Coli & 20 & 47.61 \\
Klebsiella & 10 & 23.80 \\
Enterococcus & 04 & 9.52 \\
Staphylococcus. Aureus & 02 & 4.76 \\
Pseudomonas & 06 & 14.28 \\
Moderate Deficiency & 55 & \\
Escherichia. Coli & 31 & 56.36 \\
Klebsiella & 08 & 14.54 \\
Enterococcus & 07 & 12.72 \\
Staphylococcus. Aureus & 01 & 1.81 \\
Pseudomonas & 08 & 14.54 \\
\hline
\end{tabular}

$(\mathrm{p}=0.637)$. It was significantly high in female as compare to male $(60 \%$ vs. $41.7 \%$; $p=0.042)$ It was not statistically significant with fever as shown in Table-II. Mild vitamin D deficiency was present in $42(53.16 \%)$ children, while moderate deficiency in $55(69.62 \%)$ children. E Coli was the most common pathogen in both mild and moderate vitamin D deficiency ie 20 (47.61) and $31(56.36 \%)$ respectively (Table-III).

\section{DISCUSSION}

Vitamin-D provides immunity against foreign invaders due to widespread presence of vitamin-D receptors. It has an important role in infectious diseases. In this present study vitamin-D level was positively correlated with UTI in children. Treatment of UTI is challenging due to antibiotics resistance, side effects of antibiotics, and recurrence of infection.

In this study the average age of the patients was $41.51 \pm 18.34$ months. There were $76.74 \%$ male and $23.6 \%$ female. Most of the children had fever. In Merrikhi et al. study, ${ }^{15}$ there were more girls 31 (93.9\%) presented with urinary tract infection, with a mean age of $5.97 \pm 2.90$ years.

A recent study reported that in vitamin-D deficient children, 76 (63\%) had UTI and 44 had no UTI. ${ }^{16}$ In our study frequency of vitamin-D deficiency in children with diagnosed UTI was $45.93 \%$. In another study children with UTI 12
(33.3\% had vitamin-D levels between 12-19 ng/ $\mathrm{mL}^{17}$ El-Mazary et al. found no differences in the frequency of UTI in infants who receive Vitamin-D supplement and those who have not received supplement. ${ }^{18}$ Nielsen et al found that children who had recurrent UTI also had vitamin-D deficient. ${ }^{19}$

Various studies done to know whether vitamin-D supplement can decrease the risk of urinary tract infection or not, the results are conflicting. In a study, Vitamin-D supplement increased the risk of UTI, with a relative risk of $1.76(1.07-2.91, P<0.05){ }^{20}$ Author could not search how the vitamin $D$ supplement increases the chances of UTI. Jianhuan Yang et al. concluded in their study that upper urinary tract infection had lower vitamin-D level than those having lower UTI. Serum vitamin-D $<20 \mathrm{ng} / \mathrm{mL}$ was positively associated with the risk of UTI. Vitamin-D supplementation was associated with a decreased risk of UTI. ${ }^{21}$

In this study fever was the most common complaint $50(87.21 \%)$ in children with UTI having vitamin-D deficiency. The age between 13-48 months was the most common age 73 $(42.44 \%)$ who presents with UTI. In a metaanalysis Vitamin-D deficiency was associated with increased risk of UTI. ${ }^{22}$ In another study vitamin-D level was lower in the children with UTI. ${ }^{23}$

Limitations of the study: This was a single center study; multicenter study should be conducted to make results more robust.

\section{CONCLUSIONS}

The results of this study conclude higher frequency of vitamin-D deficiency in children having UTI. Children having urinary tract infection should be assessed for vitamin-D level as deficiency could be corrected and recurrent UTI can be prevented.

Suggestions: Further studies are needed to assess whether correction of vitamin D may prevent UTIs in children. We included children having the first episode of UTI, children having recurrent UTI should also be assessed.

\section{Grant Support E Financial Disclosures: None.}

\section{REFERENCES}

1. Weydert JA. Vitamin D in Children's Health. Children (Basel). 2014;1(2):208-226. doi: 10.3390/children1020208 
2. Erol M Yigit O, Kucuk SH, Gayret OB. Vitamin D deficiency in children and adolescents in Bagcilar, Istanbul. J Clin Res Pediatr Endocrinol. 2015;7(2):134-139. doi: 10.4274/ jcrpe.1888

3. Basu S, Gupta R, Mitra M, Ghosh A. Prevalence of vitamin $\mathrm{d}$ deficiency in a pediatric hospital of eastern India. Indian J Clin Biochem. 2015;30(2):167-173. doi: 10.1007/s12291014-0428-2

4. Tekin M, Konca C, Celik V, Almis H, Kahramaner Z, Erdemir A, et al. The association between vitamin d levels and urinary tract infection in children. Horm Res Paediatr. 2015;83(3):198-203. doi: 10.1159/000370046

5. Jianhuan Y, Guangdao C, Dexuan W, Minguang C, Chao X, Bin W. Low serum 25-hydroxyvitamin D level and risk of urinary tract infection in infants. Medicine. 2016;95(27):4137. doi: 10.1097/MD.0000000000004137

6. Van der Starre WE, van Nieuwkoop C, Thomson U. Urinary proteins, vitamin $\mathrm{D}$ and genetic polymorphisms as risk factors for febrile urinary tract infection and relation with bacteremia: a case control study. PLoS One. 2015;10:121. doi: 10.1371/journal.pone.0121302

7. Shalaby SA, Handoka NM, Amin RE. Vitamin D deficiency is associated with urinary tract infection in children. Arch Med Sci. 2018;14(1):115-121. doi: 10.5114/aoms.2016.63262

8. Sood A, Penna FJ, Eleswarapu S, Pucheril D, Weaver $\mathrm{J}$, Wagner JC, et al. Incidence, admission rates, and economic burden of pediatric emergency department visits for urinary tract infection: data from the nationwide emergency department sample, 2006 to 2011. J Pediatr Urol. 2015;11:246.e1-e8. doi: 10.1016/j.jpurol.2014.10.005

9. Leung AK, Wong AH, Leung AA, Hon KL. Urinary tract infection in children. Recent Pat Inflamm Allergy Drug Discov. 2019; 13:2-18. doi: 10.2174/1872213X13666181228154940

10. Youssef DA, Ranasinghe T, Grant WB, Peiris AN. Vitamin D's potential to reduce the risk of hospital-acquired infections. Dermatoendocrinology. 2012;4:167-175. doi: 10.4161/derm. 20789

11. Zasloff M. Antimicrobial peptides of multicellular organisms. Nature. 2002;415:389-395. doi: $10.1038 / 415389 a$

12. Chromek M, Slamova Z, Bergman P, Kovacs L, Podracka L, Ehren I, et al. The antimicrobial peptide cathelicidin protects the urinary tract against invasive bacterial infection. Nat Med. 2006;12:636-641. doi: 10.1038/nm1407

13. Justice SS, Hung C, Theriot JA, Fletcher DA, Anderson GG, Footer MJ, et al. Differentiation and developmental pathways of uropathogenic Escherichia coli in urinary tract pathogenesis. Proc Natl Acad Sci USA. 2004;101:13331338. doi: $10.1073 /$ pnas. 0308125100

14. Gordon CM, DePeter KC, Feldman HA, Grace E, Emans SJ. Prevalence of vitamin D deficiency among healthy adolescents. ArchPediatr Adolesc Med.2004;158(6):531-537. doi: 10.1001/archpedi.158.6.531

15. Merrikhi A, Ziaei E, Shahsanai A, Kelishadi R, Mehr M. Is vitamin $\mathrm{d}$ supplementation effective in prevention of recurrent urinary tract infections in the pediatrics? A randomized triple-masked controlled trial. Adv Biomed Res. 2018;1-5. doi: 10.4103/abr.abr_149_18

16. Georgieva V, Kamolvit W, Herthelius $M$, Luthje $P$, Brauner A, Chromek M. Association between vitamin D, antimicrobial peptides and urinary tract infection in infants and young children. Acta Paediatrica. 2019;108(3):551-556. doi: 10.1111/apa.14499
17. Hacıhamdioglu DO, Altun D, Hacıhamdioglu B, Cekmez F, Aydemir G, Kul M, et al. The association between serum 25-hydroxy vitamin D level and urine cathelicidin in children with a urinary tract infection. J Clin Res Pediatr Endocrinol. 2016;8(3):325. doi: 10.4274/jcrpe. 2563

18. El-Mazary AM, Maaboud MA, Momen MM, Nasef KA. Vitamin D supplementation and the risk of infections in full term infants: Correlations with the maternal serum Vitamin D. Egypt J Pediatr Allergy Immunol. 2012;10:8794. doi: 10.4103/abr.abr_149_18

19. Nielsen KL, Dynesen P, Larsen P, Jakobsen L, Andersen PS, Frimodt-Moller N. Role of urinary cathelicidin LL-37 and human $\beta$-defensin 1 in uncomplicated Escherichia coli urinary tract infections. Infect Immun. 2014;82:1572-1578. doi: 10.1128/IAI.01393-13

20. Katikaneni R, Ponnapakkam T, Ponnapakkam A, Gensure $\mathrm{R}$. Breastfeeding does not protect against urinary tract infection in the first 3 months of life, but vitamin D supplementation increases the risk by $76 \%$. Clin Pediatr. 2009;48(7):750-755. doi: 10.1177/0009922809332588

21. Yang J, Chen G, Wang D, Chen M, Xing C, Wang B. Low serum 25-hydroxyvitamin D level and risk of urinary tract infection in infants. Medicine. 2016;95(27):e4137s. doi: 10.1097/MD.0000000000004137

22. Deng QF, Chu H, Wen Z, Cao YS. Vitamin D and urinary tract infection: A systematic review and meta-analysis. Ann Clin Lab Sci. 2019;49(1):134-142.

23. Mahmoudzadeh H, Nikibakhsh AA, Pashapour S, Ghasemnejad-Berenji M. Relationship between low serum vitamin D status and urinary tract infection in children: a case-control study. Paediatr Int Child Health. 2020;5:1-5. doi:10.7537/marsnsj180920.03

\section{Authors' Contributions:}

SQ, MNC, YM conceived, designed and did statistical analysis \& editing of manuscript.

SQ, SM, MNC did data collection and manuscript writing.

SQ, SM, MNC, YM did review and final approval of manuscript.

MNC responsible and accountable for the accuracy or integrity of the work.

1. Dr. Saba Qadir, MBBS, FCPS. Medical Officer,

2. Prof. Shazia Memon, MBBS, FCPS.

3. Dr. M. Nadeem Chohan, MBBS, FCPS. Assistant Professor,

4. Dr. Yasmeen Memon, MBBS, FCPS.

Professor of Pediatrics, Isra Medical University, Hyderabad, Sindh, Pakistan.

1-4: Department of Pediatrics, Liaquat University of Medical and Health Sciences, Hyderabad, Sindh, Pakistan. 